\title{
Shared jurisdiction between veterinarians and aqua medicine biologists in fish health-a Norwegian model for inter-professional and cross-sectoral collaboration
}

\author{
Wenche M. Kjæmpenes ${ }^{1}$ (D)
}

Received: 2 October 2018 / Accepted: 10 July 2020 / Published online: 11 August 2020

(C) The Author(s) 2020, corrected publication 2020

\begin{abstract}
This article investigates, using a sociology of profession approach, why veterinarians and aqua medicine biologists share jurisdiction in fish health in Norway. I use a fiveactor framework to highlight key events in the development of the Norwegian model for inter-professional and cross-sectoral collaboration in fish health. Veterinarians were initially the only profession involved in fish health. However, in the late 1980s, the Norwegian aquaculture industry suffered great losses due to significant disease outbreaks. Lack of scientific knowledge about the disease causing the outbreaks, Hitra disease, and lack of veterinary capacity to cope with the problem resulted in a situation in which veterinarians continued, as an early response to the disease, to use antibioticbased therapies. The marine science milieu, with support from the aquaculture industry, instituted a vaccine solution to the endemic Hitra disease in 1987. This scientific breakthrough had major impacts on combatting fish diseases and on the further development of vaccines. New vaccine solutions for other diseases, such as furunculosis, were developed by international and multidisciplinary collaboration. Over a 7year period, the use of antibiotic-based therapy was dramatically reduced. The control of fish diseases is aquaculture's $\mathrm{X}$ factor, and without these vaccine solutions and regulation regimes, the story of Norwegian aquaculture could have been different. The successful development of the Hitra disease vaccine enabled the marine science milieu at the University of Bergen and the University of Tromsø to establish a new programme of education for aqua medicine biologists based on their own scientific knowledge base. However, their struggle for shared jurisdiction, including the right to prescribe veterinary medicine, lasted nearly 20 years. In 2005, veterinary legislation was amended, and in addition to medical doctors, dentists and veterinarians, aqua medicine biologists, as the fourth profession in Norway, gained the right to prescribe medical products. I argue that the experience in Norway, where professionals from two different
\end{abstract}

Wenche M. Kjæmpenes

wenche.kjempenes@uit.no

Extended author information available on the last page of the article 
sectors share jurisdiction and work side by side in fish health, is worth examining as a model for organizing inter-professional and cross-sectoral collaboration.

Keywords Veterinary profession - Aqua medicine biologists · Professionalization - Shared jurisdiction · Work field · Aquaculture · Fish health · Inter-professional and cross-sectoral collaboration · Veterinary medicine regulation · Antibiotic · Norway · European Union

\section{Introduction}

It is remarkable that Norway, a country with a large fish production sector, has changed its veterinary legislation and allowed two professions to share jurisdiction over fish health. Practitioners of the new profession, aqua medicine biologists, ${ }^{1}$ are juxtaposed to veterinarians and may prescribe veterinary medicine for aquatic animals with the exception of marine mammals. A complex professionalization process with many actors involved at different times led to the sharing of work equally between veterinarians and aqua medicine biologists in fish health. An important event that started this process was the disease outbreaks in fish farms in the mid-1980s. The outbreaks were threatening the whole industry, and the use of antibiotics increased even more rapidly than the production of farmed fish. Scientists from the marine research milieu developed an effective cold-water vibriosis vaccine in 1987. This knowledge breakthrough was a decisive factor for the division of work between the two professions. Since the 1990s, Norway, as the leading salmon producer in the world, has increased its production with almost no use of antibiotic agents. In a global context, this is unique (Grave and Brun 2016, p. 73).

To gain more insight into the driving forces that have led to this unique situation in which two professions share jurisdiction over tasks in a new field of work, I apply a sociology of profession approach. The theoretical framework that brings together an actor perspective (Burrage et al. 1990) and a perspective from inter-professional competition (Abbott 1988) enables the systematization of empirical data while at the same time incorporating other theoretical perspectives (Kjæmpenes 2013). In the investigation, I focus on the scientific, professional and institutional controversies arising from the crisis caused by endemic disease outbreaks in the mid-1980s as well as on the debate that followed upon the veterinary legislation.

In "The data collection and analytic framework" I present the analytic framework for the analysis and detail how I reassembled data from earlier comparative research and supplied new material for analysis. "The Norwegian veterinary profession and aqua medicine biologists" section consists of a short presentation on the development of the Norwegian aquaculture industry and its role as a user of professional services. In "The aquaculture industry in Norway - a brief introduction to the users of professional services" and "Fish disease outbreaks and knowledge discourse in the 1980s" sections, I examine the scientific, professional and institutional processes that led the state to

\footnotetext{
${ }^{1}$ The formal Norwegian title is fiskehelsebiolog (fish health biologist), which translated into English is aqua medicine biologist. An aqua medicine biologist is distinct from the English fish health biologist, which refers to biologists who are engaged in work related to fish health but who are not fish health professionals. In this article, fish health biologist and aqua medicine biologist are synonyms for the Norwegian profession fiskehelsebiolog.
} 
award shared jurisdiction in fish health to two professions. The focus will be on scientific controversies that arose during the fish health crisis in the mid-1980s, the establishment of fish health education and the legislative debate that followed. In "The reopening of the Veterinary Surgeons Act — veterinarians lose their monopoly in fish health" section, there is a short discussion, which is followed by concluding remarks.

\section{Data collection and analytic framework}

The data collected in a qualitative comparative $\mathrm{PhD}$ study of professionalization and the division of labour in farmed fish health in Norway and Scotland (Kjæmpenes 2013) are re-examined in a new analytical context with a special focus on the Norwegian case. A combination of sources was used in the research from 2013, including interviews with central informants from public services, universities and research institutions; public documents; articles in newspapers and journals, such as Norsk Veterincertidsskrift (the Norwegian Veterinary Record), Norsk Fiskeoppdrett (Norwegian Aquaculture) and Fiskehelse (Fish Health); and annual reports, governmental documents, statistics and secondary literature, such as social science studies in aquaculture. In this article, the sources are supplemented with data from scientific articles, Norwegian legislation, European Union (EU) legislation, scientific reports, statistics, public documents and online newspapers, such as Ilaks.no and Kyst.no. The applied five-actor perspective has helped in grasping the significance of events as they appear through the sources. The purpose has been to analyse through dialogue between theory and data how events are significant markers for transition (Abrams 1994; Kjæmpenes 2013).

This article addresses how occupational expert groups and professions operate in a new work field and explores why Norway is the only country in Europe that allows two professions to share jurisdiction in fish health. Jurisdiction is often used to describe the profession's formal control of professional services (through authorization, for example). Professions tend to demand a monopoly; however, the kind of jurisdiction settlement achieved within a system of professions defines the profession's control of the work field. To develop a jurisdiction, the control of skills and knowledge is essential. Abbott (1988) states that there are several possible settlements for jurisdictional disputes, including full and final jurisdiction, subordination, the splitting of jurisdiction into interdependent parts, the granting of advisory control of certain aspects of the work to one profession and, occasionally, shared jurisdiction without a division of labour. A profession might find jurisdiction vacant or fight for it and claim the authority to institute a system of diagnosis, inferences and treatments that embodies the cultural logic of the professional practice. However, a familiar inter-professional way to settle matters of jurisdiction is also subordinated jurisdiction, such as the subordination of nursing under medicine. It is very rare for two professions to hold full jurisdiction equally without a division of tasks in a particular work field. Abbott (1988) addresses how dominance and subordination are established and reproduced in the interrelationship between professions and how jurisdictional interaction takes place both in the workplace and in more formal public and legal environments.

Whereas Abbott's main focus was on the interrelation between professions and workplace, the actor framework developed by Burrage et al. (1990) addresses both the 
interplay and tension between professions and other key actors that influence the work field. The framework of Burrage et al. (1990) is developed for comparative analyses of professionalization processes and helps in systematizing actors' interests in these processes and the resources the actors have at their disposal to influence them. In order to include a consideration of the interplay and tensions between professions, they build upon the following definition developed by Kocka:

Profession means a largely non-manual, full time occupation whose practice presupposes specialized, systematic and scholarly training...Access depends upon passing certain examinations which entitle to titles and diplomas, thereby sanctioning its role in the division of labour.... [Professions] tend to demand a monopoly of services as well as freedom from control by others such as laymen, the state, etc.... Based upon competence, professional ethics and the special importance of their work for society and common weal, the professions claim specific material rewards and higher social prestige. (Kocka 1985 in Burrage et al. 1990, p. 205)

Burrage et al. identify practising professionals, the state and users of professional services and universities and other forms of advanced training institutions as key actors that determine the form and the success or failure of the professionalization process. The actors become involved at different times and mobilize their resources, interests and strategies to pursue their own objectives. The basic aim of practising professionals is to control entry into the profession and its practice. The protection and enhancement of the profession's autonomy and corporate interests require cooperation with other actors. The state both regulates the work of professions and affords them the opportunity for advancement (Burrage et al. 1990). Professions working within the public sector are more influenced by the relationship between state and profession than professions working in the private sector since their autonomy and status depend on the state (Dent et al. 2016). Only the state or assemblies of states have the 'authority to grant and enforce monopolies and restrictive arrangements' (Muzio et al. 2011, p. 811). The EU is an example of an assembly of states that has authority to grant a profession monopoly. ${ }^{2}$ The users of professional services have influence through their strategies and preferences and how they organize themselves (Muzio et al. 2011). The form of knowledge that survives as a professional solution is determined by users' confidence (trust) in the profession's ability to solve problems on their behalf (Halvorsen 1995; Muzio et al. 2011). Universities and other advanced training institutions provide the knowledge base and official credentials and certifications that support professional closure regimes (Muzio et al. 2011).

Abbott (1988) describes the interrelation between one profession and other professions or knowledge-based groups in the development of jurisdiction. Extending the framework of Burrage et al. (1990) to a five-actor framework by incorporating other

\footnotetext{
${ }^{2}$ In 1998, EU regulations on food safety and veterinary matters were included in the European Economic Area (EEA) agreement with veterinary matters, including the authorization and right to prescribe veterinary medicine Norges offentlige utredninger NOU 2012:2 Utenfor og innenfor : Norges avtaler med EU vol NOU 2012:2. Departementenes servicesenter, Informasjonsforvaltning, Oslo. ISSN 0333-2306 ISBN 978-82583-1123-9. The EEA consists of the EU member states plus Norway, Iceland and Liechtenstein.
} 
professions or knowledge-based groups as one of five key actors opens up the possibility of scrutinizing how a profession's projects are influenced by rival occupations equipped with an alternative knowledge base and ability to solve problems (Kjæmpenes 2013; Muzio et al. 2011). According to Abbott, a profession develops 'when jurisdictions become vacant, which may happen because they are newly created or because an earlier tenant has left them altogether or lost its firm grip on them' (Abbott 1988, p. 3). It is within this five-actor framework (practising professionals, the state, the users, universities and other advanced training institutions and other professions or knowledge-based groups) that I examine why Norway has developed a model with shared jurisdiction between veterinarians and aqua medicine biologists in a newly created work field.

\section{The Norwegian veterinary profession and aqua medicine biologists}

The pioneering work of Carr-Saunders and Wilson on professions describes the veterinary surgeon as one of the classic professions (Carr-Saunders and Wilson 1933). Hellberg uses the professionalization of veterinarians in Sweden as an example to explain the relationships between higher education and the labour market, which takes the form of a struggle by the professions for a monopoly (Hellberg 1978). In Norway, the veterinary profession is included as one of 21 professions in a volume on the history of Norwegian professions (Messel and Slagstad 2014). Elvbakken's study of veterinarians and food control illustrates how microbiological and bacteriological research in veterinary medicine in the 1860 s provided useful knowledge for food inspection. It also demonstrates how the interplay of food control, administration and research was important for the professionalization of the Norwegian veterinary profession (Elvbakken 2017). In 1900, veterinary issues were placed under the authority of the Ministry of Agriculture (Horne 1925), and since then, the interrelationship between the Ministry of Agriculture and the veterinary profession has been strong (Asdal 2005; Kjæmpenes 2013).

In the 1960s, pond fish suffered disease outbreaks caused by the import of live fish and roe. Representatives of pond fish farmers, fish biologists and veterinary institutions requested the Ministry of Agriculture to investigate how to prevent the spread of fish diseases. The Ministry of Agriculture in consultation with the Directorate for Hunting, Game Preservation and Fresh Water Fishing (Direktorat for jakt, viltstell og ferskvannsfiske) set up a committee of experts in 1967. Experts from the Ministry of Fisheries were not represented in this committee. The committee recommended immediate legislative action (Ot.prp.nr. 41 1967-1968). The Diseases of Freshwater Fish Act of $1968^{3}$ was seen as closely related to the Animal Diseases Act of $1962^{4}$ (Ot.prp.nr 52 1996-1997 Chapter 2). The former designated several diseases as notifiable, meaning they should be reported to a public veterinarian. With the rapid development of the fish farming industry in Norway, the demand for services in fish health increased. Although veterinarians had jurisdiction in fish health through the Diseases of Freshwater Fish Act 1968, the field was not given priority by veterinary authorities in the 1980 s

\footnotetext{
${ }^{3}$ The short title in Norwegian is Fiskesjukdomslova av1968 (the Diseases of Fish Act).

${ }^{4}$ The Norwegian title is Lov om tiltak mot dyresykdommer av 8.juni 1962 (Husdyrloven 1962).
} 
(Kjæmpenes 2013). This opened an opportunity for other knowledge-based groups to become involved in the new work field.

In the 1980s, the aqua medicine biologist profession did not exist. However, an important basis for the creation of aqua medicine biology was the development of a vaccine by the marine science milieu in 1987 and the establishment of fish health studies at the University of Bergen in 1988 and at the University of Tromsø in 1989. The first aqua medicine biologists graduated in 1993 in Bergen and 1994 in Tromsø (Kjæmpenes 2013). However, it was not until 2001 that the graduates were juxtaposed with fish health veterinarians and gained authorization to prescribe medicine for aquatic animals other than marine mammals. The right to requisition veterinary medicine would not apply until the date decided upon by the Ministry of Agriculture (Dyrehelsepersonelloven 2001). ${ }^{5}$ The EU directive (Directive 2001/82/EC) relating to veterinary medical products had to be changed to allow professions other than veterinarians to prescribe veterinary medical products. In 2004, Directive 2001/82/EC was amended to allow member countries of the EU and European Economic Area (EEA) to decide whether a professional person is qualified to prescribe veterinary medical products. In 2007, the Norwegian Ministry of Health and Care changed the regulations on medicines from pharmacies and decided that aqua medicine biologists could requisition veterinary medicine. ${ }^{6}$ Now, for the first time, veterinarians and aqua medicine biologists equally share jurisdiction in fish health.

In the following, I highlight significant episodes in the development of a Norwegian model for shared jurisdiction that facilitate inter-professional and cross-sectoral collaboration in fish health. I investigate the key actors involved in scientific disputes in fish disease research in the 1980s, the settlement of these disputes, the establishment of fish health studies and the legislative debate that followed over authorization and prescription rights for aqua medicine biologists.

\section{The aquaculture industry in Norway-a brief introduction to the users of professional services}

Today, responsible aquaculture is believed to be key to meeting the world's growing demand for fish. The Food and Agriculture Organization (FAO) defines aquaculture as 'the farming of aquatic organisms in both coastal and inland areas involving interventions in the rearing process to enhance production' (FAO 2020). Atlantic salmon dominates in Norwegian aquaculture. Salmon are anadromous and divide their lives between freshwater and seawater. In their early life stage, they live in freshwater, while their main growth phase occurs in seawater before they return to freshwater to reproduce. Salmon farming 'therefore occurs in both freshwater hatcheries (hatchery and nursery) and seawater (on-growing to harvest)' (Kenyon and Davies 2018, p. 4). The salmon production cycle is complex and comprises subsectors such as breeding, hatchery, a nursery stage and a seawater stage where the smolts are grown in seawater.

\footnotetext{
${ }^{5}$ The English version of Dyrehelsepersonelloven is the Act of 15 June 2001 No. 75 relating to veterinarians and other animal health personnel. See https://www.regjeringen. no/globalassets/upload/lmd/vedlegg/dyrehelsepersonelloven-engelsk.pdf.

${ }^{6}$ Forskrift 7 februar 2007 nr, 222 om endring i forskrift om rekvirering og utlevering av legemidler for apotek.
} 
Seawater production varies from 18 months to 2 years (Kenyon and Davies 2018). Aquaculture production in the EU includes fish and other aquatic organisms, such as molluscs and crustaceans as well as plants for human consumption. In 2017, Norwegian production exceeded in value that of the entire EU (Eurostat 2019). Norway's total production of fish for food in 2017 was 1.3 million tonnes (almost exclusively salmon) worth EUR 7 billion, while the EU countries in 2017 produced an estimated 1.4 million tonnes aquatic organisms worth an estimated EUR 1.5 billion (Eurostat 2019). In 2017, five EU members - Spain (23\%), the UK (16.3\%), France (13.8), Italy (11.4) and Greece $(9.2 \%$ ) - were responsible for about three-quarters of the EU's total output of aquatic organisms (Eurostat 2019). The aquaculture industry in Norway has undergone significant restructuring over the last few decades. Norway has been the leading producer of Atlantic salmon in the world, and Norwegian production grew from $100 \mathrm{t}$ in 1971 (Norges offentlige utredninger NOU 1977:39) to 44,832 $\mathrm{t}$ in 1986 and 1,236,354 t in 2017 (see Table 1).

Despite serious outbreaks of disease, the industry has grown steadily. The aquaculture's rapid development in the 1980s, combined with increasing disease problems, created a demand for knowledge-based advice in fish health. In 1991 and 1992, the industry experienced a decrease in production caused by earlier overproduction and problems with excess in the salmon market. The problems resulted in the collapse of a giant freezing project in 1991 that led to the bankruptcy of the Norwegian Fish Farmers Sales Organization (Fiskeoppdretternes Salgslag; FOS), a group that had a monopoly on regulating the first sales of salmon and trout (Kjæmpenes 2013). Because of the FOS bankruptcy, no production numbers were registered in 1991, but in 1993, the numbers were already increasing again (see Table 1).

Fish farmers are users of professional services, and the resources at their disposal depend on the growth of the industry and owner structure. The growth of the industry is well documented in the production numbers shown in Table 1. Fish farming in Norway is regulated by licences, which also affect owner structure. The first temporary Fish Farming Act, favourable to small-scale farmers, was passed in 1973, and the Fish Farming Act of 1981 replaced it. Until the 1970s, the industry was dominated by smallscale and unorganized farmers with few available resources. With the establishment of the Norwegian Fish Farm Association (Norsk Fiskeoppdretteres Forening; NFF) in

Table 1 Annual production of Atlantic salmon (in tonnes) in Norway during 1978, 1980-2000, 2004, 2008, 2014, 2017 and 2018 (Statistics Norway 2020)

\begin{tabular}{lrrrrrrrrr}
\hline Year & 1978 & 1980 & 1981 & 1982 & 1983 & 1984 & 1985 & 1986 & 1987 \\
\hline $\begin{array}{c}\text { Prod. in } \\
\text { tonnes }\end{array}$ & 4389 & 4312 & 8418 & 10,695 & 17,299 & 21,882 & 29,473 & 44,832 & 46,452 \\
$\begin{array}{l}\text { Year } \\
\text { Prod. in } \\
\text { tonnes }\end{array}$ & $\mathbf{1 9 8 8}$ & $\mathbf{1 9 8 9}$ & $\mathbf{1 9 9 0}$ & $\mathbf{1 9 9 1}$ & $\mathbf{1 9 9 2}$ & $\mathbf{1 9 9 3}$ & $\mathbf{1 9 9 4}$ & $\mathbf{1 9 9 5}$ & $\mathbf{1 9 9 6}$ \\
$\begin{array}{l}\text { Year } \\
\begin{array}{c}\text { Prod. in } \\
\text { tonnes }\end{array}\end{array}$ & $\mathbf{1 9 9 7}$ & 111,338 & 145,990 & & 124,137 & 155,580 & 202,460 & 261,521 & 297,557 \\
\hline
\end{tabular}


1970, fish farmers lobbied for further government involvement in research, funding and state veterinary services (Kjæmpenes 2013). In 1978, the FOS was established and given a monopoly over the regulation of the first sales of salmon and trout by fish farmers, and all fish farms were obliged to be members. The organization was funded by a levy drawn equally from farmers and purchasers. Close contact between the FOS and NFF provided them with a good position from which to negotiate with the state (Kjæmpenes 2013; Shaw and Gabbott 1990).

Salmon production continues to increase, followed by increased income from sales. Along with the increase in production, fish farmers obtain a stronger position as organized users. During the 1980s, the NFF criticized the veterinary authorities for poor provision of public veterinary services with regard to fish farming. The NFF's annual meeting in 1981 formulated a statement in which they asked the government to give priority to veterinary services and prepare a plan as soon as possible, in cooperation with the NFF, on future veterinary services for the fish farming industry. The background for this statement was a letter from the NFF Board in which they asked the NFF to agitate for more coordinated research between the Norwegian Institute of Marine Research (Havforskningsinstituttet) in Bergen and the Norwegian Veterinary Institute (Veterinærinstituttet) in Oslo (Norsk Fiskeoppdrett 1981).

In 1983, the FOS, NFF and Research Council of Norway established the Frisk Fisk (Healthy Fish) project. One of the motivations for starting this project was the repeated outbreak of the so-called Hitra disease, or cold-water vibriosis (Vibrio salmonicida), in the 1980s. Fish farmers, through their organization, the NFF, lobbied for collaboration between researchers from fishery and agricultural research institutions. The FOS part of the funding of the Frisk Fisk project was important, and when the FOS was dissolved in 1991, its support for the Frisk Fisk project ceased (Kjæmpenes 2013). This project that the users of public fish health services, the fish farmers, initiated ensured interdisciplinary and cross-sectoral research cooperation in an important and crucial period for knowledge development in fish health. The problem for the industry in the early 1980s was fourfold: it lacked support from the government, veterinary services had not adapted to the situation created by the growth of the industry, the veterinary profession as a whole did not take a particular interest in fish health and there was a lack of scientific knowledge about fish diseases (Kjæmpenes 2013). In other words, fish health was an open work field that needed the involvement of knowledge-based occupations. Furthermore, according to Sandvik ${ }^{7}$ et.al., in the early 1980s, efforts to establish the necessary infrastructure, competence and capacity to tackle the considerable disease problems were 'hampered by insufficient resources, and by overlapping responsibilities and poor cooperation on the part of the authorities on the one hand and on poor discipline, competence, and cooperation on the part of many fish farmers on the other' (Sandvik et al. 1992, p. 54). The NFF wanted the Ministry of Agriculture to give priority to developing satisfactory veterinary involvement, and during the $1980 \mathrm{~s}$, criticism of the public veterinary service intensified because of increasing disease problems, with the use of antibiotics as a particular cause of concern (Kjæmpenes 2013).

\footnotetext{
${ }^{7}$ Olav Sandvik was Chief Veterinary Officer from 1983 to 1989.
} 


\section{Fish disease outbreaks and knowledge discourse in the 1980s}

Fish diseases have been and still are a critical X factor for the development of food production in aquaculture. In Norway, veterinary authorities have been involved in statutory fish disease work since the enactment of the Diseases of Fresh Water Act of 1968. The background for this early regulation and involvement from veterinary institutions was that the import of live fish and roe was expanding quickly, largely due to hatching and the restocking of rivers and lakes in the 1920s-1950s, and fish diseases were spread as a result of this import (Norges offentlige utredninger NOU 1977:39).

The expert committee set up in 1967 by the Ministry of Agriculture to investigate the need for the regulation of fish diseases recommended that several fish diseases should be notifiable. Amongst them were furunculosis, vibriosis and viral hemorrhagic septicemia. There were no controversies about expertise in the legislative work related to the Diseases of Freshwater Fish Act of 1968, and the state veterinary service gained the right and responsibility to treat diseases in freshwater fish on the basis of its knowledge of closely related animal diseases. However, according to Sandvik et al. (1992), the Veterinary Institute considered it obvious there was a need for expertise in fish diseases. Nonetheless, the Ministry of Agriculture and veterinary authorities adopted a wait-and-see attitude, and resources available for fish disease problems were meagre in the 1960s and 1970s (Sandvik et al. 1992).

With the innovation of net pens on the seabed in 1969, fish farming moved into marine water, a field in which the Ministry of Fisheries and institutions belonging to the fishery sector were involved (Kjæmpenes 2013). The development of fish health knowledge and the regulation of diseases in marine fish were affected by overlapping responsibilities between the Ministry of Agriculture and the Ministry of Fisheries. Both ministries were already deeply involved in fish farming, and so, both had responsibility for fish farming. In the government's Lysø Committee Report 1977 (Norges offentlige utredninger NOU 1977:39), the committee's majority recommended that the Ministry of Fisheries assume overall responsibility for fish farming. Until then, the only legal regulation on administrative and jurisdictional responsibilities in the aquaculture industry was the Diseases of Freshwater Fish Act of 1968 and the temporary Fish Farming Act of 1973. The committee recommended that the veterinary experts within the state veterinary service under the Ministry of Agriculture continue to oversee the treatment of freshwater fish, and the government followed the report's majority recommendations, settling the dispute between representatives from the agriculture and fishery sectors. However, disagreement continued between the two ministries about responsibility for diseases in marine water, and in 1984, the Ministry of Agriculture appointed a working group with members from the Ministry of Agriculture, the Ministry of Fisheries and the Norwegian Fish Farmers' Association to investigate some circumstances surrounding fish diseases and the future structure of the veterinary service for fish farming (Kjæmpenes 2013). Since the Ministry of Fisheries had overarching responsibility for the fish farming industry, and marine species fell under their stewardship, the question of whether marine species should be included in the Diseases of Freshwater Fish Act of 1968 became complicated. The ministries managed separate administrative fields and had not traditionally worked together, but the situation required them to cooperate. In the 
report from the working group, the Ministry of Fisheries' representative stated that a new fish diseases act, which would include freshwater fish and marine species, would bring in new administrative responsibility and new expert agencies. The conflict of interest between the ministries and their expert agencies ${ }^{8}$ became very clear as there was no agreement in the report about whether to include marine species in the Diseases of Freshwater Fish Act of 1968 (Kjæmpenes 2013). This was an agreement that was necessary for the further structure of veterinary service for fish farming. Another working group, appointed in 1987 by the prime minister, recommended that the veterinary authority assume responsibility for common fish diseases affecting all aquatic animals, but this was not in line with the interests of the Ministry of Fisheries and the Directorate of fisheries (Kjæmpenes 2013). Meanwhile, marine fish farming expanded quickly, still without laws regulating diseases in marine species. In 1990, the temporary Diseases of Fish Act was passed, which applied to both farmed and wild freshwater fish as well as marine fish in captivity, but it did not include wild marine fish. After seven years, this temporary act was replaced by the Diseases of Fish Act of 1997, which included marine aquatic animals and sea mammals. The Ministry of Agriculture and the Ministry of Fisheries agreed to establish a coordinating agency headed by the Ministry of Fisheries to organize activities dealing with questions on fish. This new act finally settled the 15-year-long dispute between the two ministries. The division of administrative responsibility for fish health opened the work field for both marine and veterinary science and fostered the development of shared jurisdiction between the veterinary profession and aqua medicine biologists.

During the ongoing legislative debate in the 1980s between the two ministries and their member institutions and belonging experts about responsibility for fish diseases, there were severe outbreaks of vibriosis in sea cages that made the need for disease control in farmed marine species clear. The only response to the disease available to veterinarians was antibiotic-based therapy. Although the production of salmon increased in the 1980 s, the use of antibiotics increased even more rapidly (see Fig. 1). In 1987, 48,570 kilos of antibiotics were used for the production of 46,000 t (Asche et al. 2009), and veterinarians were the only profession that could prescribe them.

Figure 1 shows a very high use of antibiotics until 1993 and a dramatic reduction of the use after 1993. In the 1980s, the veterinary system did not manage to respond to the demand for expertise in the fish health field, and the public veterinary service structure could not meet the fish farming industry's need. Antibiotics mixed into the feed treated the disease outbreak, and Norwegian veterinary and marine scientists debated the cause of the vibriosis that was threatening the industry in the 1980s. It was marine scientists who managed to develop the first vibriosis vaccine, which was commercially introduced in 1991. However, other diseases emerged in the late 1980s and early 1990s, presenting a further challenge to the industry. For example, furunculosis outbreaks due to infected smolts imported from Scotland caused significant losses until oil-adjuvanted vaccines, developed through international and interdisciplinary collaboration, were introduced in the early 1990s, reducing these losses (Kjæmpenes 2013). In the mid-

\footnotetext{
${ }^{8}$ The Veterinary Department (Veterinæravdelingen) at the Ministry of Agriculture and the Directorate of Fisheries at the Ministry of Fisheries.
} 


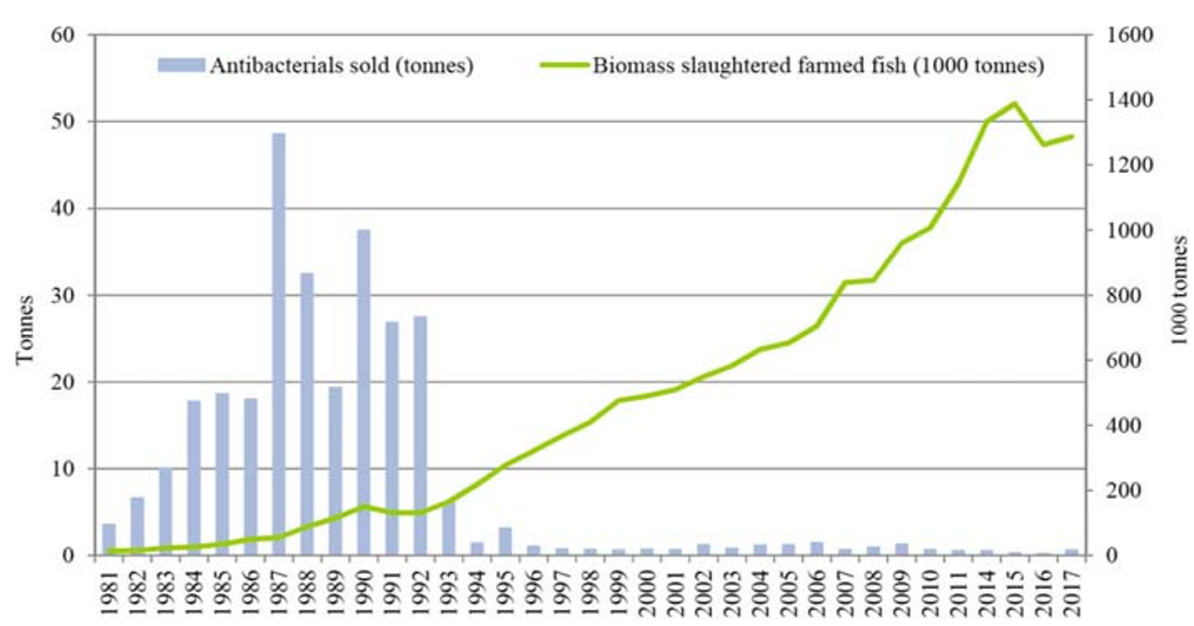

Fig. 1 Graph of sales, in tonnes of active substance, of antibacterial veterinary medicinal products for therapeutic use in farmed fish in Norway in 1981-2011 and 2014-2017 versus produced biomass (slaughtered) farmed fish. Adapted from Norm-Vet (NORM/NORM-VET 2017, p. 19)

1990s, the use of antibiotics was reduced dramatically, such that only 511 kilos of antibiotics were prescribed for the production of 1.3 million farmed fish in 2014 (Norwegian Veterinary Institute 2016). The vibriosis vaccines were part of the measures that reduced disease-related problems and the use of antibiotics, and their development documented the marine science milieu's ability to develop valuable knowledge that contributed to avoiding a disease crisis. The universities, which wanted to establish new educational programmes on fish disease, could now lean on marine science, providing an important supplement to veterinary science. Fish diseases became a new scientific field along with aquaculture, and according to Abbott, herein lies an example of a profession's ability 'to sustain its jurisdiction partly in the power and prestige of its academic knowledge' (Abbott 1988, pp. 53-54). Fish disease was not a traditional research field either in veterinary or marine science. However, this changed with the development of the aquaculture industry. Norwegian salmon farming was developing faster than any optimist could have envisioned. At the same time, this rapid development challenged how agriculture and fishery institutions used science and occupational expert groups. Historically, the Norwegian agricultural sector has been autonomous and has educated members of its own professions (i.e. agronomists and veterinarians) (Kjæmpenes 2013). For its part, marine research also has a long tradition that dates back to the nineteenth century, but the sector does not have the same historical tradition of educating its own professions (Jacobsen 1965). It is in this context that I now examine more closely the scientific dispute about vibriosis, otherwise called Hitra disease.

Vibriosis, or cold-water vibriosis, occurred on a large scale for the first time in 1979 on a fish farm on the island of Hitra, giving it the name Hitra disease. Veterinary scientists and marine scientists/microbiologists argued over the cause of the disease, and in a status report from the Frisk Fisk research programme groups, this disagreement was evident (Frisk Fisk 1987). In this report, veterinarian Trygve Poppe mentions the professional Hitra disease disagreement in a summary of a research project on a different disease, exocrine pancreatic disease: 
As we know, there is considerable professional disagreement between different Norwegian research milieus about this. Some are of the opinion that this is foremost about an infection caused by bacteria, whereas others, amongst them the veterinary science milieu, including the Veterinary Institute, claim that the salmon suffer from one of several basic illnesses caused by a nutritional or metabolism problems that leave the fish exposed to secondary infections, amongst them the bacterium suggested as being Vibrio salmonicida...A number of causal conditions of 'Hitra disease' cannot be explained by bacteria alone... nutrition, bacteria, environment, and perhaps viruses, are conditions that work together and form the complex that is called the Hitra diseases. (Poppe 1987 in Kjæmpenes 2013, p. 216). ${ }^{9}$

In this same status report, the Frisk Fisk project group stated that:

A vaccine has been developed against Vibrio salmonicida. This vaccine will now be able to be used by the Norwegian fish farmers. There is hope that the vaccine will help to keep the disease down in the future, but at the same time, all the conditions around the disease must improve. (Frisk Fisk 1987) ${ }^{10}$

In 1987, the vaccine was tested, and Trond Jørgensen from the University of Tromsø states in the same status report from the Frisk Project "the "Hitra disease" puzzle...that despite everything is not a puzzle anymore, but a bacterial disease in line with classical vibriosis' (Jørgensen 1987 in Kjæmpenes 2013, p. 217). ${ }^{11}$ The veterinary authorities allowed the fish farmers to test the vaccine in 1987, and Vibrio salmonicida was listed as a notifiable disease. Since the introduction of this vaccine, the disease has not caused damaging problems for the industry (Kjæmpenes 2013). The fish farmers, the users of professional services, have funded fish disease research, and as a result, new knowledge about diseases has laid the foundation for the marine scientists to develop a new vaccine. The marine scientists proved that their knowledge could help solve the industry's disease problem caused by the Hitra disease.

\section{The reopening of the Veterinary Surgeons Act-veterinarians lose their monopoly in fish health}

In 1994, the Norwegian Government realized the need to reopen the Veterinary Surgeons Act of 1948. The reopening was caused by radical changes in animal husbandry, the need to include all animal health personnel and challenges caused by the rapid development of the fish farming industry (Ot.prp.nr.52 2000-2001). Fish were not included in the 1948 Act. However, the veterinary profession was responsible for freshwater fish diseases, as stipulated by the Diseases of Fish Act of 1968, and was therefore involved in fish health.

\footnotetext{
${ }^{9}$ Kjæmpenes (2013) has translated the text from Norwegian into English.

${ }^{10}$ Kjæmpenes (2013) has translated the text from Norwegian into English.

${ }^{11}$ Kjæmpenes (2013) has translated the text from Norwegian into English.
} 
As described above, knowledge about several processes in progress and involved actors within the same period affected the legislative debate on fish health. There had been a lack of government commitment to tackling the increased diseases in farmed fish during the 1980s, and the veterinary authority lacked funding for research and sufficient veterinarians with an interest in fish health work. This situation opened the scientific work field for the marine research milieus at the Universities of Bergen and Tromsø, which established a fish health study. In 1989, the University of Tromsø applied for their graduates to have restricted permission to prescribe medicine to diseased fish. This application was denied because the graduates lacked competence to prescribe medicine, and their knowledge of pharmacology was too limited. However, the Ministry of Education and Research asked the University of Tromsø to adjust its application according to comments made by the Ministry of Agriculture's chief veterinary officer, which could open the possibility for a new hearing. The Chief Veterinary Officer was against this new application, though, and stated that the case would not be returned to the universities (Kjæmpenes 2013). After the denial of the first application, the University of Tromsø had frequent contact with the Ministry of Education and Research. In 1993, the Ministry of Church, Education and Research arranged a meeting in which five ministries, two directorates and two universities were represented. ${ }^{12}$ The mandate for the meeting was to clarify "whether it was advisable that graduates of fish health should share parts of the veterinary profession's sphere of responsibility and competence' (Kjæmpenes 2013, p. 220). The Ministry of Church, Education and Research concluded that it was advisable that the two universities send a new application to the Ministry of Social Affairs. However, the Ministry of Agriculture's Veterinary Division responded to the letter by stating that both the Ministry of Agriculture and Norwegian Food Safety Control objected to this new application and that ' $[\mathrm{t}]$ he liberalization of the right to prescribe medicines might provoke a reaction from the export market e.g. the EU... The right to prescribe medicine to fish should be more restricted rather than be extended' (Letter from the Ministry of Agriculture (Veterinary Division) to the Ministry of Church, Education and Research. 12 October 1993) (Kjæmpenes 2013, p. 221). ${ }^{13}$

The first aqua medicine biologists graduated from the University of Bergen in 1993 and the University of Tromsø in 1994 without being allowed to prescribe medicine. In 1995, a new working group appointed by the Ministry of Agriculture ${ }^{14}$ considered incorporating prescription rights for aqua medicine biologists into the legal system. The working group submitted a divided proposal (Kjæmpenes 2013). During a visit to Tromsø in April 1995, the prime minister at the time, Gro Harlem Brundtland, was thoroughly informed about prescription rights by the rector Ole D. Mjøs of the University of Tromsø and the rector Bjørn Hersoug of the Norwegian College of Fishery Science. This became, according to Killie, a political turning point in which

\footnotetext{
12 The institutions represented were the Ministry of Church, Education and Research the Ministry of Agriculture, the Ministry of Fisheries, the Ministry of the Environment, the Ministry of Social Affairs, Norwegian Food Safety Control, the Directorate of Health, the University of Troms $\varnothing$ and the University of Bergen (minutes from a meeting on 18 December 1990 which dealt with the fish health study).

13 The text is translated by Kjæmpenes (2013).

14 The working group was appointed in 1994 and had members from the Ministry of Agriculture, the Ministry of Fisheries, the Ministry of Social Affairs and Health, the Norwegian Health Control Authority and the Norwegian Medicine Control Authority.
} 
the government instructed the ministries to come to an agreement about allowing aqua medicine biologists to prescribe medicine (personal communication from Associate Professor Jan-Eirik Angell Killie, the Norwegian College of Fishery Science, University of Tromsø June 2018). In the white paper (St meld nr. 48 [1994-1995]), with the title 'Havbruk' (Aquaculture), the government stated that its aim was for aqua medicine biologists to be granted the right to prescribe medicine, and in June 1996, the ministries agreed that it was 'technically justifiable for fish health biologists to have prescribing rights' (Kjæmpenes 2013, p. 221). At the same time the process regarding the application of aqua medicine biologists for prescription rights was taking place, the Veterinary Surgeons Act of 1948 was reopened. The bill relating to veterinarians and other health personnel received its first hearing in 1996, and after this hearing, it became clear that changes in the public veterinary system were so significant that they had consequences for the structure of the bill. The bill was sent to its second hearing in 2000 . Finally, in this bill, aqua medicine biologists were given the authorization and right to requisition prescriptions for aquatic animals with the exception of marine mammals. Even though there were several comprehensive changes in the bill, such as on the use of medicine, cooperation and the distribution of duties in animal health, which demonstrated that the government wanted to organize the veterinary service to a larger degree, the question about prescription rights for aqua medicine biologists was a major issue in the hearing comments (Kjæmpenes 2013). The Norwegian Board of Health Supervision, the Norwegian Medical Association, the Veterinary Association and the Norwegian Pharmacy Association did not want to allow aqua medicine biologists to prescribe medicine. They argued that if they were given prescription rights, this could increase requisitioning for prescription medicines only, with the risk that Norwegian fish farming could lose its credibility (Kjæmpenes 2013; Ot.prp.nr. 52 [2000-2001]). All consultation bodies agreed that 'according to EEA Agreement Directives 81/851/ EØF and Directive 00/37/EF, veterinarians would only be qualified to prescribe veterinary medicine. Thus, the EEA Agreement Directives would have to be changed before authorization and prescribing rights could be granted' (Kjæmpenes 2013, p.224). In 2001, the act relating to veterinarians and other animal health personnel (Dyrehelsepersonelloven 2001) was enacted, replacing the Veterinary Surgeons Act of 1948. The Norwegian Veterinary Association informed their colleges in the Federation of Veterinarians of Europe and the European Union of Veterinary Practitioners that the Norwegian Government would probably 'lobby to change the EU regulation in order to give fish health biologists the prescribing rights for fish' (Kjæmpenes 2013, p. 224). The British Veterinary Association took note of the Norwegian case and supported the Norwegian Veterinary Association's attempt to stop the lobbyists. In 1995, the Federation of Veterinarians of Europe (FVE) supported in a resolution the Norwegian Veterinary Association's recommendation of granting veterinarians the sole right to prescribe medicine:

It is the opinion of the FVE that the sole right of veterinarians to prescribe medicine is essential for the efficient protection of public health and environment. The prescribing right is based upon the ethos of the veterinary curriculum combining pharmacology, toxicology, pathology, veterinary medicine, and preventive veterinary medicine, with microbiology, virology parasitology, food 
hygiene and public health in all species of animal and food animal origin, including fish. (FVE Resolution cited in Norsk Veterinærtidsskrift 1996, no. 4, p. 272)

The work with the EU Commission continued. The Universities of Tromsø and Bergen and the Fish Health Association (Fiskehelseforeningen), established in 1997, worked with the Ministry of Agriculture and avoided open confrontations with the veterinary profession. The University of Bergen asked the ministry for permission to bring their own jurist to join their meetings with the ministry and convinced the ministry that it was possible within EU regulations to obtain a licence to prescribe medicine for aqua medicine biologists. The ministry continued its work nationally in persuading the EU Commission to allow other than veterinarians to prescribe medicine. In 2005, Directive 2004/28/EC amended Directive 2001/82/EC on the community code relating to veterinary medical products, allowing member states to decide who was qualified to prescribe veterinary prescriptions: 'Any prescription for a veterinary medicinal product issued by a professional person qualified to do so in accordance with applicable national law' (Directive 2004/28/EC, Article 1, section 21).

It took many years and many involved actors (users, universities and research institutions, ministries) before the aqua medicine biologists could finally celebrate the end of a battle to be allowed to prescribe medicine for fish. However, to be able to prescribe medicines in Norway, it was necessary to obtain a licence from the Norwegian Medicines Agency. Only doctors, dentists and veterinarians were mentioned in the regulation in 2005 . In 2007, after nearly 20 years, all necessary regulations were amended, and veterinarians and aqua medicine biologists were finally juxtaposed in the fish health field.

\section{Discussion and concluding remarks}

The main contribution of this article is to advance understandings of how occupational expert groups and professions operate in a new work field and how the interrelations between actors (both institutional and individual actors) determine the success of a professionalization process. In his theory of professions, Abbott states that shared jurisdiction without a division of labour occurs occasionally (Abbott 1988). With a five-actor framework for analysing the Norwegian fish health case, the complex processes that take place in order to reach shared jurisdiction between two professions comes to the fore. The aquaculture industry in Norway, with its rapid development and the involvement of actors from different institutions and sectors, has influenced how the professionalization of a work field takes place. 'Individual actors may play an important role in the development of a new profession or institutions, but the interrelationship between actors defines the space of action' (Kjæmpenes 2013, p. 247).

I consider the scientific dispute and institutional controversies around the Hitra disease to be events that have had a major impact on the development of the Norwegian model for shared jurisdiction. Knowledge is often developed in a continuous struggle for alternative forms, as experienced in this project. Even though the veterinary profession already had jurisdiction in fish health, the new work field demanded new scientific knowledge and was therefore open to the involvement of other occupational 
expert groups. Universities were driving forces in the professionalization process of aqua medicine biologists and equipped the new occupational expert group with a knowledge base that made it possible to professionalize. However, it is not possible to study professionalization processes without involving institutional processes, both national and international. The Norwegian state, in this case, has a very strong interest in promoting fish health through disease and food control as well as control of the threat posed by the use of antibiotics. The Norwegian fish farming industry began with many small-scale fish farms. Today, however, large multinational companies are powerful players in the industry. It is in this context that the interplay between actors (industry, professions, other professions and occupational expert groups, universities and the state) has taken place. The development of the Hitra disease vaccine in the 1980s is a good example of how to reduce the use of antibiotics. It is a story not only about successful knowledge development and the professionalization of aqua medicine biologists but also about how a public fish disease service is provided by two sectors and two professions, one in close contact with agriculture and veterinary science and one in close contact with marine science. The interplay between the state institutions, professions and occupational groups from the agriculture and fishery sector, as shown for example in the science and legislative debate, has been decisive for the development of the shared jurisdiction model. The government, the aquaculture industry and the universities as well as the aqua medicine biologists considered shared jurisdiction an effective way of organizing tasks in fish health services. In the professionalization processes, it is this interrelationship between the actors that defines the arena of action, and by combining already-existing theories of professions, it has become possible to trace important paths leading to the shared jurisdiction model.

The national context of knowledge production in fish health has given the industry an advantage in the global market. The collaboration between the agriculture and fishery sectors and their member institutions has been part of the success of developing effective disease management regimes. I argue that without the complex professionalization process in the fish health field that resulted in shared jurisdiction between veterinarians and aqua medicine biologists, effective disease management regimes promoting inter-professional and cross-sectoral collaboration might not have developed in Norway. The introduction of vaccines reduced the use of antibiotics dramatically, as shown in Fig. 1, and the Norwegian aquaculture industry is now a world leader in reducing the use of antibiotics. An effective disease management regime developed because of inter-professional and cross-sectoral cooperation (although reluctant at the start). However, there are still great challenges in regard to outbreaks of fish diseases, and the Norwegian industry has not yet encountered other crises as severe as the Hitra disease. The vaccine breakthrough in the 1980s has provided an international platform for fish disease and vaccine research. The use of antibiotics in Norwegian farmed fish still remains very low (NORM/NORM-VET 2018). On their website, the Veterinary Institute states, in a comment on the decline in antibiotic consumption and resistance in animals in Norway, that the low use of antibiotics in farmed fish is primarily 'due to access to efficient vaccines against the major bacterial diseases and complete vaccination coverage of fingerlings' (Norwegian Veterinary Institute 2019).

What lesson can be learned from the Norwegian inter-profession and cross-sectoral model of shared jurisdiction in fish health? Recent approaches to profession sociology argue that control over jurisdictional boundaries must be analysed at a global level 
(Carvalho and Santiago 2016). For example, EU regulations on human and animal medicine directly affect the interrelationships between professions in their national context. Antibiotic resistance is one of the biggest threats to global health and food security. It is estimated that about 33,000 people die annually in Europe due to the resistance of pathogenic bacteria to antibiotics (European Centre for Disease Prevention and Control 2018). In Norway, there are about 70 deaths annually as a result of resistant bacteria (Norwegian Institute of Public Health 2018). The number is predicted to rise if no actions are taken. To combat antimicrobial resistance, the EU wants to achieve a harmonized and more restrictive and proper use of antimicrobials in animal husbandry. It has responded to the situation with legislation that grants a monopoly to the veterinary profession in its role in animal and fish health, adopting in autumn 2018 a new veterinary regulation to strengthen the existing framework for fighting antimicrobial resistance. In particular, one regulation, Regulation (EU) 2019/6, aims to end the practice of using antibiotic-preventive and growth-promoting drugs in livestock production. The regulation gives the veterinary profession the exclusive right to diagnose and discharge veterinary medicine. According to the current directive on the community code relating to veterinary medical products, any prescription for a veterinary medicinal product must be issued by a professional person qualified to do so in accordance with applicable national law (Directive 2004/28/EC, Article 1, point 21). Given the low aquaculture production in the EU compared to Norway, it is timely to ask whether giving veterinarians (many without experience in aquaculture) the exclusive right to issue veterinary prescriptions for fish is a sensible measure. For Norway, the largest producer of farmed fish in Europe, shared jurisdiction between the two professions will no longer be possible if the EU does not allow Norway through the EEA agreement to decide who is allowed to prescribe veterinary medicine.

One of the key issues addressed by this paper is how jurisdiction is created and fought for by professions. With the changes in EU regulations, a new debate about jurisdiction in Norwegian fish health has begun. The president of the Norwegian Veterinary Society, Torill Moseng, welcomes the new regulations. She states that Norway has reduced the use of antibiotics by $99 \%$ in fish farms. If the veterinarians and aqua medicine biologists continue their successful collaboration, the changes in EU directives about the prescription of veterinary medicine will have little practical significance (Moseng 2018). Alternatively, the president of Tekna Havbruk og Helse, ${ }^{15}$ Kristoffer B. Andreassen, states that aqua medicine biologists must as a profession have access to the entire toolbox, including prescribing medicine in order to perform their professional tasks (Andreassen 2018). Eight large fish health service companies employing both veterinarians and aqua medicine biologists sent a letter dated 8 November 2018 to the Norwegian Ministry of Health and Care Services, the Norwegian Ministry of Agriculture and Food and the Norwegian Ministry of Trade Industry and Fisheries in which they expressed their concern about the new EU directive that will affect the recruitment of aqua medicine biologists to the field. If the profession is deprived of the right to prescribe antibiotics, the collective preparedness of Norwegian fish health will deteriorate, which may affect fish welfare negatively. In their

\footnotetext{
${ }^{15}$ Tekna is the Norwegian Society of Graduate Technical and Scientific Professionals. Tekna Havbruk og Fiskehelse (Tekna Aquaculture and Fish Health) is organized under their umbrella and is the aqua medicine biologists' association.
} 
estimation, the Norwegian aquaculture industry's future growth depends on authorized veterinarians and aqua medicine biologists with special expertise in fish health and fish welfare (Akvavet Gulen et al. 2018). The debate shows similarities with the legislative debate of the 1990s.

The Norwegian model of promoting collaboration between sectors through shared jurisdiction and professions demonstrates that it is possible to think differently in combatting the use of antibiotics. It might not be the solution for all nations since the role of professions has traditionally been closely related to national contexts. However, the latest changes in the EU directives show the importance for studies of professions to consider how transnational institutions might form the knowledge that survives as a professional solution to safeguard the interests of society.

Funding Open access funding provided by UiT The Arctic University of Norway (incl University Hospital of North Norway).

\section{Compliance with ethical standards}

Conflict of interest The author declares that she has no conflict of interest.

Open Access This article is licensed under a Creative Commons Attribution 4.0 International License, which permits use, sharing, adaptation, distribution and reproduction in any medium or format, as long as you give appropriate credit to the original author(s) and the source, provide a link to the Creative Commons licence, and indicate if changes were made. The images or other third party material in this article are included in the article's Creative Commons licence, unless indicated otherwise in a credit line to the material. If material is not included in the article's Creative Commons licence and your intended use is not permitted by statutory regulation or exceeds the permitted use, you will need to obtain permission directly from the copyright holder. To view a copy of this licence, visit http://creativecommons.org/licenses/by/4.0/.

\section{References}

Abbott, A. (1988). The system of professions: an essay on the division of expert labor. Chicago: University of Chicago Press.

Abrams, P. (1994). Historical sociology. New York: Cornell University Press.

Akvavet Gulen AS, Aqua Kompetanse AS, HaVet AS FA, FoMas AS, Marine Helse AS, \& Labora AS. (2018). Felles uttalelse til EU-forordningen som kan innskrenke fiskehelsebiologenes reseptrett. Letter 8 November 2018 to Helse og omsorgsdepartementet, Nærings og fiskeridepartementet, Landbruks- og matdepartementet, https:/www.akerbla.no/uploads/images/Felles-uttalelse-i-saken-om-innskrenking-avreseptretten-for-fiskehelsebiologer-8.11.201811941.pdf. Accessed 27 Mar 2020.

Andreassen, K. B. (2018). Tap av reseptrett=underkjenning av fiskehelsekompetanse. Kyst.no, https://www. kyst.no/article/tap-av-reseptrett-underkjenning-av-fiskehelsekompetanse/. Accessed 26 Mar 2020.

Asche, F., Hansen, H., Tveteras, R., \& Tveterås, S. (2009). The salmon disease crisis. Chile Marine Resource Economics, 24(4), 405-411.

Asdal, K. (2005). Grensetrafikk: nedslag i matpolitikkens og veterincervesenets historie. Oslo: Unipub.

Burrage, M., Jarausch, K., \& Siegrist, H. (1990). An actor-based framework for the study of the professions. In M. Burrage \& R. Torstendahl (Eds.), Profession in theory and history: rethinking the study of the professions (pp. 201-225). London: Sage.

Carr-Saunders, A. M., \& Wilson, P. A. (1933). The professions. Oxford: Clarendon.

Carvalho, T., \& Santiago, R. (2016). Professionalism and knowledge. In M. Dent, I. L. Bourgeault, J.-L. Denis, \& E. Kuhlmann (Eds.), The Routledge companion to the professions and professionalism (pp. 144-157). New York: Routledge, Abingdon Oxon. 
Dent, M., Bourgeault, I. L., Denis, J.-L., \& Kuhlmann, E. (2016). General introduction. the changing world of professions and professionalism. In M. Dent, I. L. Bourgeault, J.-L. Denis, \& E. Kuhlmann (Eds.), The Routledge companion to the professions and professionalism (pp. 1-10). New York: Routledge, Oxon.

Directive 2001/82/EC. Directive 2001/82/EC of the European Parliament and of the Council of 6 November 2001 on the community code relating to veterinary medicinal products. Official Journal of the European Communities J. 28.11.2001, L 311/1-66. https:/eur-lex.europa.eu/LexUriServ/LexUriServ.do?uri= OJ:L:2001:311:0001:0066:en:PDF. Accessed 27 Mar 2020.

Directive 2004/28/EC. Directive 2004/28/EC of the European Parliament and the Council of 31 March 2004 amending Directive 2001/28/EC on the community code relating to veterinary medical products, Official Journal of the European Union, L 136/58. https:/ec.europa.eu/health/sites/health/files/files/eudralex/vol5/dir_2004_28/dir_2004_28_en.pdf. Accessed 26 Mar 2020.

Dyrehelsepersonelloven (2001). Lov 15 June 2001 no 75 om veterinærer og annet dyrehelsepersonell. https://lovdata.no/dokument/NL/lov/2001-06-15-75. Accessed 27 Mar 2020.

Elvbakken, K. T. (2017). Veterinarians and public health: Food control in the professionalization of veterinarians. Professions and Professionalism, 7(2), 1806 https://journals.hioa.no/index. php/pp/article/view/1806. Accessed 27 Mar 2020.

European Centre for Disease Prevention and Control (2018). 33000 people die every year due to infections with antibiotics-resistant bacteria. https:/www.ecdc.europa.eu/en/news-events/33000-people-die-everyyear-due-infections-antibiotic-resistant-bacteria. Accessed 26 Mar 2020.

Eurostat (2019). Fishery statistics. https://ec.europa.eu/eurostat/statistics-explained/index.php/Fishery_ statistics. Accessed 27 Mar 2020.

FAO (2020). Food and Agriculture Organization, Aquaculture. http://www.fao.org/aquaculture/en/. Accessed 27 Mar 2020.

Frisk Fisk. (1987). Status rapport fra programgruppen. Trondheim: Fiskeoppdretternes Salgslag.

Grave. K., \& Brun, E. (2016). Use of antibiotics in Norwegian aquaculture on behalf of the Norwegian seafood council. Oslo: Norwegian Veterinary Institute. https://seafood.no/contentassets/c5a14b9acf3b4f1 b9753263586513a68/use-of-antibiotics-in-norwegian-aquaculture.pdf. Accessed 25 Mar 2020.

Halvorsen, T. (1995). Sektorinteresser eller profesjonssystem? (10), TMV skriftserie, Senter for teknologi og menneskelige verdier. Universitetet i Oslo.

Hellberg, I. (1978). Studier i profesjonell organisastion. En profesjonsteori med tillämpning på veterinäyrket. Studies in professional organization. A theory of professions applied to the veterinary profession. Uppsala: Department of Sociology, Uppsala Universitet.

Horne, H. (1925). Veterincervesenets historie. Oslo: Cappelen.

Jacobsen, K. D. (1965). Informasjonstilgang og likebehandling i den offentlige virksomhet. Tidsskrift for samfunnsforskning, 6, 147-160.

Kenyon, W., \& Davies, D. (2018). Salmon farming in Scotland. The Scottish Parliament. https://sp-bpr-enprod-cdnep.azureedge.net/published/2018/2/13/Salmon-Farming-in-Scotland/SB\%2018-12\%20rev.pdf. Accessed 26 Mar 2020.

Kjæmpenes, W. M. (2013). Fish diseases - who cares and who cures? A comparative study of professionalization and division of work in the health of farmed fish in Norway and Scotland. Bergen: University of Bergen.

Messel, J., \& Slagstad, R. (2014). Profesjonshistorier. Oslo: Pax.

Moseng, T. (2018). Forvirring rundt veterinærer og fiskehelsebiologer. President i den Norske veterinærforening. ilaks.no. https://ilaks.no/forvirring-rundt-veterinaerer-og-fiskehelsebiologer/. Accessed 25 Mar 2020.

Muzio, D., Kirkpatrick, I., \& Kipping, M. (2011). Professions, organizations and the state: Applying the sociology of the professions to the case of management consultancy. Current Sociology, 59(6), 805-824.

Norges offentlige utredninger NOU 1977: 39 (1977). Fiskeoppdrett. Oslo-Bergen-Tromsø: Universitetsforlaget: Fiskeridepartementet. (Official Norwegian Reports NOU).

NORM/NORM-VET (2017). Usage of antimicrobial agents and occurrence of antimicrobial resistance in Norway. https://www.vetinst.no/overvaking/antibiotikaresistens-norm-vet. Accessed 22 Mar 2020.

NORM/NORM-VET (2018). Usage of antimicrobial agents and occurrence of antimicrobial resistance in Norway. https://www.vetinst.no/overvaking/antibiotikaresistens-norm-vet. Accessed 23 Mar 2020.

Norsk Fiskeoppdrett (1981). Årsmøte i Norske Fiskeoppdretteres Forening. Medlemsblad for Norske Fiskeoppdretteres Forening, (4), 2-3, 6-9.

Norsk Veterinærtidsskrift. (1996). FVE resolution - fish health in Norway. Norsk veterincertidsskrift, 4, 272.

Norwegian Institute of Public Health (2018). Antibiotikaresistens er årsaka til 33000 dødsfall kvart år i Europa. https://www.fhi.no/nyheter/2018/antibiotikaresistens-er-arsaka-til-33-000-dodsfall-kvart-ar-ieuropa/. Accessed 26 Mar 2020. 
Norwegian Veterinary Institute (2016). Use of antibiotics in Norwegian aquaculture. Report 22. Oslo: The Norwegian Veterinary Institute. file:///C:/Users/wkj000/Downloads/ 201622 Use\%20of\%20Antibiotics\%20in\%20Norwegian\%20Aquaculture.pdf. Accessed 26 Mar 2020.

Norwegian Veterinary Institute (2019, 19 September). Decline in antibiotic consumption and resistance in animals in Norway. https:/www.vetinst.no/en/news/decline-in-antibiotic-consumption-and-resistance-inanimals-in-norway. Accessed 23 Mar 2020.

Ot.prp.nr 52 (1996-1997). Om lov om tiltak mot sykdom hos fisk og andre akvatiske dyr (fiskesykdomsloven). Oslo: Landbruksdepartementet. https://www.regjeringen.no/no/dokumenter/otprpnr-52-1996-97-/id158608/?ch=1. Accessed 26 Mar 2020. (Proposisjon to the Storting [bill]).

Ot.prp.nr. 41 (1967-1968). Om lov om tiltak mot sjukdommer hos ferskvannsfisk. Stortingsforhandlinger (ib.utg.). 1967/68, 112(4b). Oslo: Landbruksdepartementet. (Proposisjon to the Storting [bill]).

Ot.prp.nr.52 (2000-2001). Om lov om veterinærer og annet dyrehelsepersonell. Oslo: Landbruksdepartementet. https://www.regjeringen.no/no/dokumenter/otprp-nr-52-2000-2001-/id164515 1. Accessed 26 Mar 2020. (Proposisjon to the Storting [bill]).

Regulation (EU) (2019). Regulation (EU) 2019/6 of the European Parliament and the Council of 11 December 2018 on veterinary medical products and repealing Directive 2001/82/EC. Official Journal of the European Union L 4/43. https://eur-lex.europa.eu/eli/reg/2019/6/oj. Accessed 26 Mar 2020.

Sandvik, O., Næss, B., Race, J. A., \& Norge, L. (1992). Animal health standards in Norway: A historical perspective and assessment of the existing situation. Oslo: Royal Ministry of Agriculture.

Shaw, S. A., \& Gabbott, M. (1990). An international study of the marketing of farmed salmon vol. In 05/ 1990. Bergen: Rapport Senter for anvendt forskning.

St meld nr 48 (1994-1995). Havbruk - en drivkraft i norsk kystnæring. Oslo: Fiskeridepartementet. https://www.regjeringen.no/no/dokumenter/stmeld-nr-48-1994-95/id464075/. Accessed 26 Mar 2020.

Statistics Norway (2020). Aquaculture. Sales of slaughtered fish for food, by fish species (C) 1976-2018. https://www.ssb.no/en/statbank/table/07326. Accessed 26 Mar 2020.

Publisher's note Springer Nature remains neutral with regard to jurisdictional claims in published maps and institutional affiliations.

\section{Affiliations}

\section{Wenche M. Kjæmpenes ${ }^{1}$}

1 Faculty of Humanities, Social Sciences and Education, UiT The Arctic University of Norway, Follumsvei 39, Alta, 9509, Norway 